\title{
UPAYA KESBANGPOL KABUPATEN CIANJUR DALAM MEMINIMALISIR KONFLIK PADA MASA PERSIAPAN PILPRES DAN WAPRES TAHUN 2019
}

\author{
Harky Ristala ${ }^{1}$ \\ ${ }^{1}$ Program Studi Ilmu Pemerintahan, Fakultas Ilmu Sosial dan Ilmu Politik, \\ Universitas Jenderal Achmad Yani, Indonesia
}

\begin{abstract}
Abstrak
Tujuan dalam penelitian ini adalah Untuk mengetahui dan mendeskripsikan Upaya Kesbangpol Kabupaten Cianjur Dalam Meminimalisir Konflik Pada Masa Persiapan Pilpres dan Wapres Tahun 2019. Metode dalam penelitian ini menggunakan penelitian kualitatif, dalam penelitian kualitatif menggunakan metode kualitatif yaitu pengamatan, wawancara dan penelaahan dokumen. Berdasarkan hasil penelitan dapat di simpulkan bahwa dalam meminimalisir konflik pada masa persiapan Pilpres dan Wapres tahun 2019 cenderung baik. Upaya kesbangpol Kabupaten Cianjur dalam meminimalisir konflik pada masa persiapan Pilpres dan Wapres tahun 2019 berupa terjalinnya komunikasi yang efektif antara semua elemen dengan masyarakat. Faktor pendukung SDM, anggaran, SOP dan juknis, dan optimalisasi media sosial. Sementara, faktor penghambat adalah SDM, anggaran, sarana dan prasarana, cuaca, dan rendahnya budaya literasi di masyarakat sehingga mudah di hasut dengan informasi hoax.
\end{abstract}

Kata kunci: Upaya, Konflik, Pilpres

\begin{abstract}
The purpose of this research is to know and describe the efforts of Kesbangpol Cianjur Regency in Minimizing Conflict during the Preparation Period for the Presidential Election and Vice President in 2019. The method in this study uses qualitative research, in qualitative research using qualitative methods namely observation, interviews and document review. Based on the results of the research, it can be concluded that in minimizing conflict during the preparation for the 2019 Presidential Election and Vice President, it tends to be good. Kesbangpol Cianjur Regency's efforts to minimize conflicts during the preparation for the 2019 Presidential and Vice Presidential Election were in the form of effective communication between all elements and the community. Supporting factors for human resources, budget, SOP and technical guidelines, and optimization of social media. Meanwhile, the inhibiting factors are human resources, budget, facilities and infrastructure, weather, and the low literacy culture in the community so that they are easily provoked by hoax information.
\end{abstract}

Keywords: Effort, Conflict, Presidential Election 


\section{PENDAHULUAN}

Segenap bangsa Indonesia dan seluruh tumpah darah Indonesia, berkehendak untuk memajukan kesejahteraan umum, serta menegakkan hak asasi setiap warga negara melalui upaya penciptaan suasana yang aman, tenteram, tertib, damai dan sejahtera, baik lahir maupun batin sebagai wujud hak setiap orang atas pelindungan agama, diri pribadi, keluarga, kehormatan, martabat, dan harta benda. Oleh karenanya, segala perseteruan dan/atau benturan antar kelompok masyarakat dapat mengakibatkan terganggunya stabilitas nasional dan terhambatnya pembangunan nasional.

Pada tahu 2019 menjadi momentum sebagai pesta demokrasi di Indonesia karena menyelenggarakan pemilihan umum secara bersamaan, namun di balik itu semua ada sebuah kerawanan konflik yang tercipta ditengah-tengah masyarakat. Potensi kerawanan konflik tersebut ialah akibat dari Pileg dan Pilres diselenggarakan secara serentak. Kerawanan muncul karena bukan sekadar pertarungan antarcaleg, namun partai politik juga akan berusaha keras meraih suara nasional empat persen agar lolos ke Senayan. Pada Pilpres pun pasangan calon dan pendukungnya juga akan berjuang mati-matian. Penggunaan strategi politik berupa politik identitas, SARA(Suku, Agama, Ras dan Antar Golongan), hoax, ujaran kebencian, kampanye hitam dan negatif, semakin meningkatkan potensi konflik sosial (Astyawan, 2019).

Dengan adanya benturan antar kelompok masyarakat pada dasarnya merupakan bentuk konflik sosial, yang menimbulkan kekerasan, suasana mencekam, perasaan takut secara meluas atau menimbulkan korban harta benda, dan nyama. Munculnya konflik sosial menyebabkan terpecah belahnya persatuan dan kesatuan antar kawan, antar kelompok, menurunnya moral bangsa dan prestasi generasi muda. Akibat dari potensi konflik sosial juga menjadi ancaman terhadap terjadinya kerusakan atau kehancuran rumah-rumah warga, fasilitas umum, kebakaran, dan penganiayaan. Oleh karena itu, konflik sosial menjadi ancaman yang menimbulkan trauma psikis, ketakutan dan terganggunya ketentraman umum yang dapat menghambat cita-cita pembangunan nasional 
(Suparmin, 2014).

Didalam upaya pencegahan konflik sosial, menurut Suparmin (2014) menyarankan (1) perlunya mengaktifkan kehadiran Kesbangpol daerah dan perangkat desa ke desa-desa/kelurahan-kelurahan secara terus-menerus, berwawasan kemitraan dan kesetaraan dengan masyarakat dan tokoh agama, tokoh masyarakat untuk diajak duduk satu meja secara bersamasama dalam mencegah dan menangani terjadinya konflik atau gangguan keamanan; (2) perlunya deteksi dini (early warning) untuk mengenali sumber-sumber penyebab konflik sosial yang dapat menimbulkan terjadinya konflik kekerasan; dan (3) perlunya menyampaikan informasi dua arah dengan pendekatan keamanan dan ketertiban masyarakat berwawasan perdamaian untuk menentramkan situasi keamanan.

Pada pelaksanaan Pilres 2019 di Kabupaten Cianjur berpotensi munculnya konflik karena merupakan wilyah dengan jumlah penduduk yang sangat banyak dan sangat potensial mendulang suara. Kabupaten Cianjur memiliki 32 kecamatan, 348 kelurahan/desa dengan jumlah penduduk sebanyak 2.149.121 jiwa. Kabupaten Cianjur juga menjadi satu dari tiga daerah lainnya di Provinsi Jawa Barat yang memiliki kerawanan tinggi terkait Pilres 2019. Disamping itu, terjadinya konflik internal partai politik (parpol) di tingkat pusat, seperti Golkar, PKS, PPP dan Demokrat, yang memberikan pengaruh terhadap kepengurusan parpol di tingkat daerah,

Berdasarkan latar belakang masalah maka dilakukan penulis tentang Upaya Kesbangpol Kabupaten Cianjur Dalam Meminimalisir Konflik Pada Masa Persiapan Pilpres dan Wapres Tahun 2019. Adapun yang menjadi rumusan masalah dalam penelitian ini ialah Bagaimana Upaya Kesbangpol Kabupaten Cianjur dalam meminimalisir konflik pada masa persiapan Pilpres dan Wapres tahun 2019. Adapun tujuan penelitian ini ialah untuk mengetahui dan mendeskripsikan Upaya yang di lakukan oleh Kesbangpol Kabupaten Cianjur dalam meminimalisir konflik pada masa persiapan Pilpres dan Wapres tahun 2019.

\section{METODE PENELITIAN}


Penelitian ini menggunakan pendekatan deskriptif, proses penelitian kualitatif bersifat seni, dan disebut sebagai metode interpretive karena data hasil penelitian berkenaan dengan interprestasi terhadap data yang ditemukan dilapangan (Sugiyono, 2012). Lebih lanjut (Sugiyono, 2012) menjelaskan bahwa metode penelitian kualitatif digunakan pada kondisi objek yang alamiah dimana peneliti sebagai instrumen kunci. Oleh karena itu penelitian ini lebih menekankan pada metode atau pendekatan penelitian deskriptif kualitatif.

Penelitian yang dilakukan ini bertempat di Kesbangpol Kabupaten Cianjur. Waktu penelitian adalah rentang waktu yang digunakan selama proses penyusunan proposal hingga penelitian berlangsung, mulai dari tahap persiapan sampai pada tahap penyusunan laporan sesuai dengan sasaran penelitian.

Pengumpulan data dalam penelitian ini peneliti akan menggunakan prosedur pengumpulan data antara lain : Observasi, dengan cara ini peneliti dapat meyakini, dapat melihat dan dapat mengamati sendiri yang kemudian dilanjutkan dengan pencatatan perilaku serta kejadian sebagai mana adanya. Wawancara, melakukan wawancara langsung kepada semua pihak yang berkompoten dalam penelitian ini, agar informasi yang didapatkan tidak meragukan dan dapat dipertanggung jawabkan. Dokumentasi, dokumentasi yakni pengumpulan data dari sumber-sumber non visual yakni berupa dokumen-dokumen atau arsip-arsip dan rekaman yang ada relevansinya dengan kebutuhan data yang dibutuhkan peneliti.

\section{HASIL DAN DISKUSI}

Menurut Baron \& Byrne (2004) konflik adalah sebuah proses di mana seseorang atau sekelompok orang mempersepsikan bahwa orang lain telah atau akan melakukan sesuatu yang bertentangan dengan kepentingannya. Terdapat beberapa elemen kunci dalam sebuah konflik yaitu (1) adanya kepentingan yang berlawanan, (2) menyadari adanya oposisi, (3) keyakinan bahwa pihak lain akan melakukan sesuatu untuk mengintervensi kepentingan mereka, (4) adanya tindakan intervensi. Saat ini keempat elemen kunci terciptanya konflik ada pada kompetisi pilpres antar, sehingga terjadinya konflik merupakan sebuah keniscayaan. 
Selanjutnya Baron \& Byrne (2004) menjelaskan konflik erat kaitannya dengan tidak terpenuhinya rasa keadilan. Akan tetapi perlu ditekankan adalah bahwa penilaian keadilan tersebut adalah di mata orang tersebut (Greenberg, 1990), sehingga orang-orang yang berbeda bisa memiliki pertimbangan keadilan yang berbeda. Karakteristik rasa keadilan ini unik, yaitu yang sensitif terhadap rasa keadilan itu adalah orang yang dirugikan, sementara orang yang diuntungkan cenderung lebih tidak sensitif. Hal ini dikenal sebagai self-serving bias.

Konflik akan muncul ketika individu merasakan tidak adanya keadilan distributive (distributive justice), yaitu penilaian individu oleh apakah mereka telah mendapatkan perlakuan yang adil; keadilan prosedur (procedural justice) yaitu penilaian individu apakah prosedur yang diterapkan terhadap mereka sudah adil; dan yang terakhir keadilan interaksional (interactional justice) yaitu sejauh mana pihak yang terlibat dapat menjelaskan pilihan-pilihannya dengan rasional.

Konflik juga mudah terjadi ketika seseorang mempunyai pandangan yang mengkategorisasi sosial (social categorization), yaitu kecenderungan orang untuk melihat dunia sosial atas dua yaitu "kami" dan "mereka" atau mindset ingroup us outgroup. In-group ialah kelompok sosial di mana seseorang merasa dirinya adalah bagian dari kami. Sementara itu out-group ialah setiap kelompok selain kelompok di mana individu itu merasa berada. Orang dan pandangan yang masuk dalam kategori "kami" mendapatkan penilaian yang positif, sementara yang lainnya negatif. Sisi buruk dari kategorisasi sosial ini adalah terciptanya prejudis, yaitu sikap negatif terhadap anggota kelompok sosial tertentu. Yang menarik adalah prejudis merupakan hasil dari pembelajaran sosial. Yang berarti ada jalan untuk melakukan konter atas prejudis dengan memberikan pembelajaran yang baru.

Dewasa kini di mana konflik semakin sering terjadi maka diperlukan langkah-langkah yang tegas untuk mengembangkan strategi baru untuk menyelesaikan konflik secara efektif. Untuk menetralisisasi konflik pada masa persiapan Pilpres maka perlu adanya usaha bersama dari berbagai pihak baik itu bagi pejabat, public figure, media massa, dan masyarakat itu 
sendiri.

\section{Meminimalisir Konflik di Wilayah Kabupaten Cianjur pada masa persiapan Pilpres dan Wapres 2019}

Meminimalisir Konflik di wilayah Kabupaten Cianjur menjelang Pilpres 2019 pada dasarnya merupakan bentuk keamanan dan ketertiban masyarakat (kamtimbas). Hal tersebut berarti keberhasilan untuk membina serta mengembangkan potensi dan kekuatan masyarakat dalam mencehah serta mengembangkan potensi dan kekuatan masyarakat dalam mencegah, menangkal, dan menanggulangi segala bentuk pelanggaran hukum dan bentuk-bentuk gangguan lainnya yang dapat meresahkan masyarakat dalam menjalankan kegiatan kehidupannya. Meminimalisir Konflik di wilayah Kabupaten Cianjur menjelang Pilpres 2019 ditunjukan ada atau tidak adanya perubahan sikap, opini dan perilaku masyarakat.

Upaya Kesbangpol Kabupaten Cianjur dalam meminimalisir konflik dengan mengkomunikasi pesan-pesan kamtibmas terkait Pilpres. Pesanpesan kamtibmas tersebut disampaikan baik secara langsung maupun tidak langsung. Secara langsung dengan bertatap muka baik melalui kegiatan kunjungan/sambang, penyuluhan, dan pembinaan, serta on air di radio. Sementara secara tidak langsung dengan menyampaikan himbauan melalui leaflet, spanduk, dan media sosial. Adapun beberapa isi pesanpesan meminimalisir konflik terkait Pilpres 2019 oleh Kesbangpol Kabupaten Cianjur antara lain:

1. Dengan Bhinneka Tunggal Ika Kita Wujudkan Pemilu 2019 Aman, Damai dan Sejuk;

2. Yuk Ciptakan Pileg dan Pilpres 2019 Aman, Damai dan Sejuk;

3. Mari Jaga Persatuan dan Kesatuan dengan Saling Menghormati: Ciptakan Pileg dan Pilpres 2019 di Kabupaten Cianjur Aman, Damai dan Sejuk;

4. Pemilu Damai Kehormatan dan Kebanggaan Seluruh Warga Kabupaten Cianjur;

5. Damai Tanpa Hoax;

6. Ayo Wujudkan Pemilu 2019 yang Aman, Damai dan Sejuk Tanpa Hoax, Politisasi SARA, dan Politik Uang; 
7. Mari Sukseskan Pileg dan Pilres 2019: Say No to Hoax, Konten Negatif Bukan Pilihan;

8. Awas Hoax dan Provokator Timbulkan Perpecahan Mari Sukseskan Pileg dan Pilpres 2019;

9. Jadilan Generasi Milenial dengan Menjadi Pemilih Cerdas;

10. Generasi Milenial Itu Generasi Tanpa Hoax dan SARA: Yuk Ciptakan Pemilu 2019 Aman, Damai dan Sejuk Tanpa Hoax dan Black Campaign.

11. Saring Sebelum Sharing: Jadilah Generasi Anti Hoaks! Cek Kebenaran Informasi Sebelum Menyebarluaskannya kembali.

12. Generasi Penerus Bangsa Itu Bijak Bermedia Sosial: Ciptakan Pemilu 2019 Aman, Damai dan Sejuk.

Hal di atas menunjukkan bahwa Kesbangpol Kabupaten Cianjur menyampaikan pesan-pesan yang berisi ajakan atau himbuan untuk menciptakan kamtibmas atau situasi kondusif dalam masa persiapan Pilpres 2019, dengan tetap mempertahankan persatuan dan kesatuan melalui sikap saling menghormati dan saling menghargai perbedaan, serta tidak mudah terprovokosi hoax serta bersikap bijaksana terkait saring informasi di media sosial. Isi pesan-pesan tersebut juga disampaikan dengan bahasa yang bersifat sederhana dan mudah dipahami, selain bahasa yang digunakan bersifat umum yang ditujukan pada masyarakat secara umum, maupun bahasa yang bersifat khusus yang ditujukan pada kelompok tertentu seperti generasi muda, mahasiswa, atau kelompok agama.

Berdasarkan hasil wawancara dengan aparatur Kesbangpol Kabupaten Cianjur yang menyatakan:

"Kami memanfaatkan radio, media online, media social serta media cetak, atau spanduk dan pamflet untuk menyampaikan pesan-pesan kemanan dan ketertiban pada masa persiapan pilpres kali ini. Misalnya, kami menjadi salah satu narasumber bersama Kodim, kepolisian dan Bawaslu di RRI mengenai Pengamanan Kampanye Terbuka Pemilu 2019 di wilayah Kabupaten Cianjur. Harapan kami masyarakat sadar bahwa penting mewujudkan pemilu aman dan 
lancar.”

Himbauan yang dilakukan oleh Kesbangpol Kabupaten Cianjur cenderung mampu membentuk opini, sikap dan perilaku masyarakat sehingga mereka memiliki pemahaman bahwa menciptakan kamtimbas merupakan suatu kebutuhan serta untuk meminimalisr konflik ditengah panasnya tensi politik pada masa persiapan pilpres. Hal ini seperti yang dikemukakan oleh kutipan wawancara dengan aparatue Kesbangpol Kabupaten Cianjur di bawah ini:

"kami sangat apresiasi adanya kesadaran pada masyarakat untuk berpartisipasi menjaga keamanan, misalnya siskamling serta sosialisasi bahaya berita hoax yang, yang ikut pun cukup banyak, jadi ini tanda positif warga mulai ada kesadaran untuk sama-sama menghindari potensi konflik akibat pilpres."

Pernyataan senada juga dikemukakan oleh Bapak Awaludin warga Kabupaten Cianjur seperti kutipan wawancara di bawah ini:

"keamanan dan kondusifitas memang tanggung jawab bersama, warga bertanggung jawab. Saya sadar keamanan penting dalam kehidupan bermasyarakat, kita wajib menjaganya. Saya coba ikut juga mensosialisasikan bahaya berita hoax terkait pemilu."

Ajakan oleh Kesbangpol cenderung mampu memotivasi masyarakat untuk berpartisipasi untuk meminimalisir potensi konflik pada masa persiapan terkait Pilpres 2019. Hal tersebut ditunjukkan dengan antusiasme LSM, Ormas serta masyarakat secara umum bergabung dalam deklarasi-deklarasi oleh para instansi terkait dalam menjaga kamtibmas. Hal ini seperti yang dikemukakan dalam kutipan wawancara dengan aparatur Kesbangpol Kabupaten Cianjur di bawah ini:

"saat ini kami telah beberapa kali menyelenggarakan deklarasideklarasi dan ternyata animo masyarakat untuk berpartisipasi tinggi. Kami juga melakukan deklarasi dengan tokoh masyarakat dan organisasi masyarakat lainnya yang ada di Kabupaten Cianjur.” 
Upaya Kesbangpol Kabupaten untuk meminimalisir konflik pada masa persiapan pilpres pada dasarnya merupakan upaya untuk melaksanakan fungsi dan peran pemerintah daerah dalam mewujudkan kamtibmas. Suasana kamtibmas yang kondusif ditunjukkan dengan tercapainya tujuan strategis dan tujuan operasional. Tujuan strategis diindikasikan dengan terwujudnya pesan-pesan pemilu damai yang disampaikan kepada masyarakat, terciptanya pemahaman mengenai kebutuhan kamtibmas oleh masyarakat, dan terwujudnya citra pemerintah daerah yang positif.

Berdasarkan temuan penelitian yang telah dijabarkan sebelumnya, maka upaya Kesbangpol Kabupaten Cianjur untuk meminimalisir konflik menjelang Pilpres 2019 di wilayah Kabupaten Cianjur diringkas dalam Gambar di bawah ini:

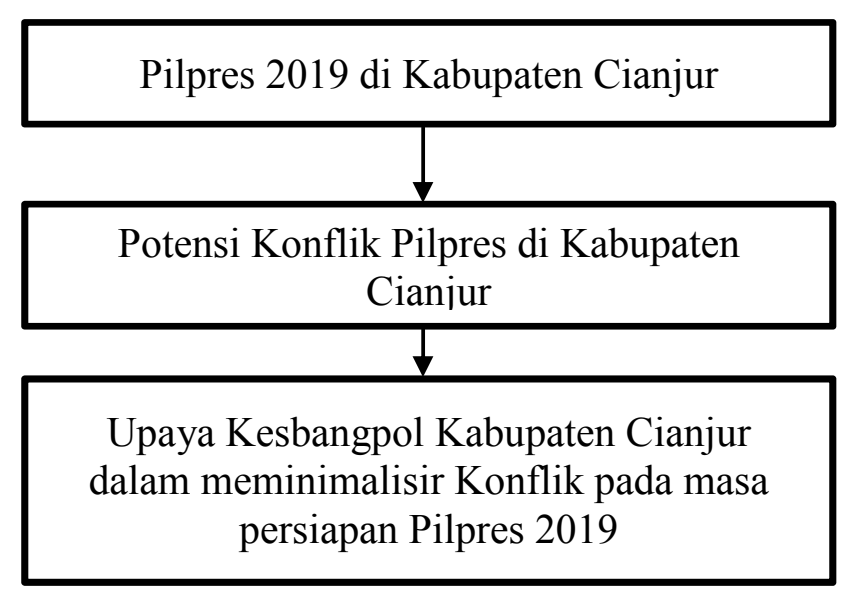




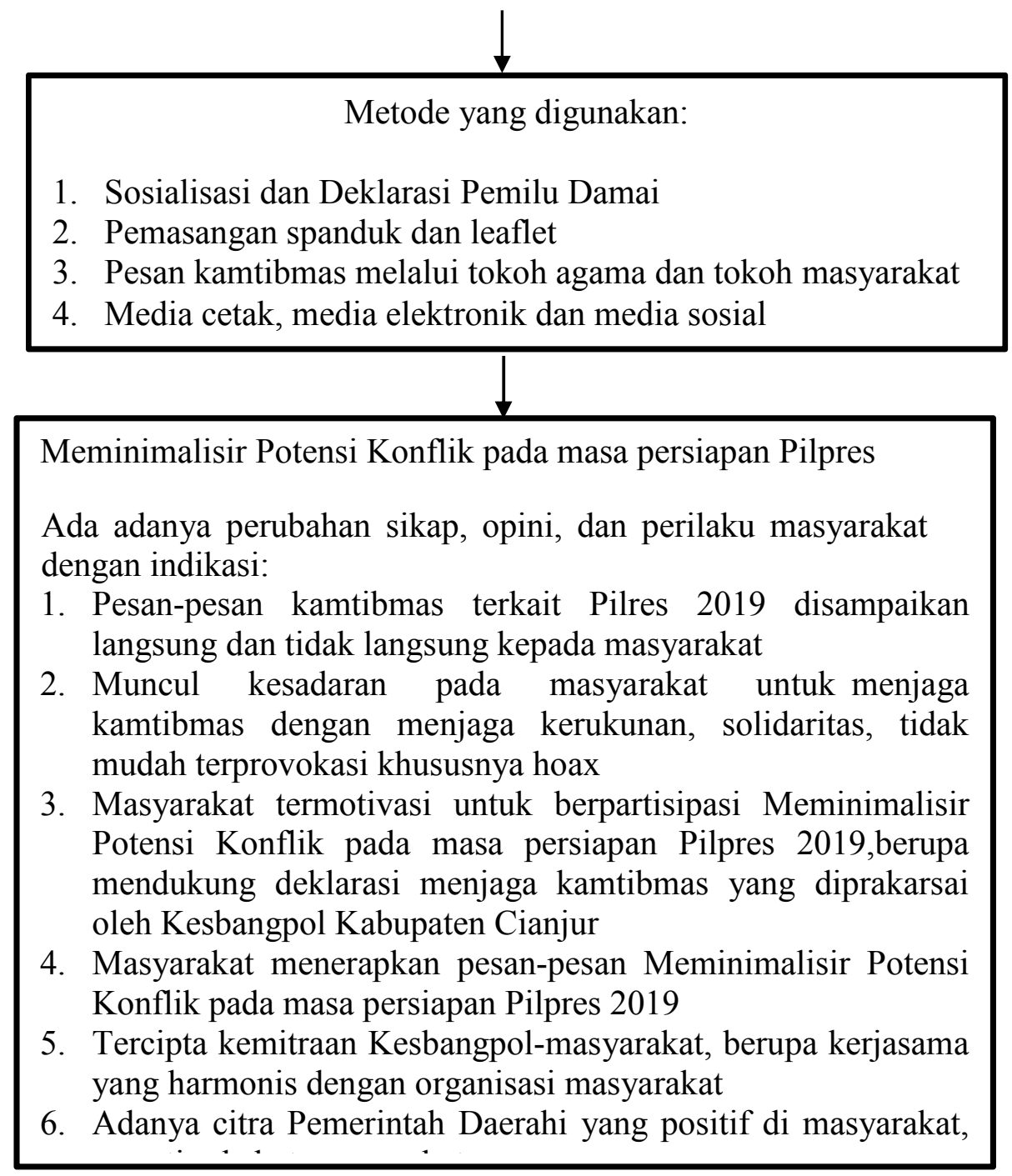

\section{Faktor Pendukung dan Penghambat dari Upaya Kesbangpol dalam Meminimalisir Potensi Konflik pada masa persiapan Pilpres 2019 di Kabupaten Cianjur}

Beberapa faktor yang mendukung upaya Kesbangpol dalam Meminimalisir Potensi Konflik pada masa persiapan Pilpres 2019 di wilayah Kabupaten Cianjur, antara lain:

\section{Sumber Daya Manusia (SDM)}

Kesbangpol Kabupaten Cianjur menyelenggarakan pelatihan fungsi baik pembinaan maupun operasional yang dilaksanakan oleh Kesbangpol Kabupaten Cianjur sehingga menambah pengetahuan dan kemampuan aparatur Kesbangpol Kabupaten Cianjur. Secara khusus, terkait upaya 
menciptakan suasana kondusif menjelang Pilres 2019 maka para aparatur Kesbangpol Kabupaten Cianjur mendapatkan pembekalan, sehingga aparatur Kesbangpol Kabupaten Cianjur menguasai dan memahami materi yang pada akhirnya dapat menjalankan tugasnya dalam pembinaan dan penyuluhan kamtibmas kepada masarakat secara maksimal. Pernyataan ini diperkuat oleh kutipan wawancara dengan Kadis Kesbangpol Kabupaten Cianjur sebagai berikut:

"Para aparatur Kesbangpol Kabupaten Cianjur dalam menjalankan tugasnya terkait sosialisasi kepada masyarakat supaya berpartisipasi dalam mewujudkan kondisi yang kondusif pada masa Pilpres 2019 telah mendapatkan pembekalan, sehingga para aparatur tersebut menguasai dan memahami materi."

\section{Anggaran}

Kesbangpol Kabupaten Cianjur mengalokasikan anggaran untuk program-program yang berkaitan dengan upaya mewujudkan kekondusifan menjelang pemilu 2019, khususnya pada program pengembangan strategi, pemberdayaan potensi keamanan, dan pemeliharaan kemanan.

3. Standard Operating Procedur (SOP) dan Petunjuk Teknis (Juknis)

Terdapat SOP dan juknis terkait kegiatan meminimalisir potensi konflik dalam rangka pengamanan pelaksanaan pemilu 2019. SOP dan juknis tersebut meliputi fungsi dan tugas bhabinkamtibmas, kompetensi dan sikap kepribadian aparatur, pelaksanaan tugas, administrasi dan kelengkapan, serta pengawasan dan pengendalian.

\section{Sosialisasi}

Kesbangpol Kabupaten Cianjur dalam rangka mewujudkan suasana kondusif di Pemilu 2019 juga mengoptimalkan fungsi media sosial. Optimalisasi fungsi media sosial ini diharapkan terjadi peningkatan jumlah followers dan militasi followers terhadap media sosial, serta peningkatan channel interaksi masyarakat sekaligus menjadikan garda terdepan penyebaran berita yang benar. Pernyataan ini diperkuat oleh hasil wawancara dengan Kepala Dinas Kesbangpol sebagai berikut:

"Kami mengoptimalkan media sosial, khususnya penyampaian pesan- 
pesan mendukung terciptanya suasana kondusif dan penyebaran berita yang benar. Media sosial yang kami gunakan yang akrab di masyarakat, seperti Istagram dan WhatsApp."

Hasil wawancara senada juga dikemukakan oleh aparatur Kesbangpol sebagai berikut:

"Kami selain menyebarkan leaflet dan spanduk yang berisi ajakan menjaga suasana kondusif, kami juga menggunakan WA untuk menyebarkan pesan-pesan pemilu damai dan penyebaran berita yang benar. WA juga menjadi sarana interaktif kami dengan masyarakat, khususnya jika beredar berita yang belum jelas kebenarannya di masyarakat."

Beberapa faktor yang menghambat upaya Kesbangpol dalam Meminimalisir Potensi Konflik pada masa persiapan Pilpres 2019 di wilayah Kabupaten Cianjur, antara lain:

1. Sumber Daya Manusia (SDM)

Terbatasnya jumlah aparatur Kesbangpol ini menyebabkan belum semua wilayah terakomodir sehingga komunikasi dengan aparatur kesbangpol tentang pemilu damai masih belum maksimal. Selain itu, masih terbatasnya kemampuan komunikasi aparatur kesbangpol dalam mempengaruhi dan menggalang masyarakat untuk menunjang pelaksanaan program pemberdayaan.

2. Anggaran

Meski terdapat anggaran terkait Pilres 2019, namun anggaran tersebut terbatas untuk kegiatan operasional sehingga berdampak padapelaksanaan tugas sehari-hari yang belum dilaksanakan secara maksimal.

3. Sarana dan prasarana

Masih terbatasnya sarana dan prasarana khusus yang dimiliki oleh Kesbangpol Kabupaten Cianjur untuk mendukung kegiatan tugas. Selain itu, pelaksanaan sosialisasi melalui media sosial masih menggunakan handphone pribadi karena belum adanya fasilitas.

4. Masyarakat 
Masyakat masih mudah terpengaruh hoax karena rendahnya literasi.

\section{KESIMPULAN}

Kesbangpol dalam Meminimalisir Potensi Konflik pada masa persiapan Pilpres 2019 di wilayah Kabupaten Cianjur cenderung baik, yang diindikasikan dengan terwujudnya pesan-pesan pemilu damai serta terkait Pilres 2019; muncul kesadaran masyarakat; berpartisipasi masyarakat meningkat; masyarakat menerapkan pesan-pesan pemilu damai; tercipta kemitraan pemerintah daerah-masyarakat yang harmonis, dan adanya citra pemerintah daerah yang positif di masyarakat, seperti sahabat masyarakat.

Kesbangpol dalam Meminimalisir Potensi Konflik pada masa persiapan Pilpres 2019 di wilayah Kabupaten Cianjur ditunjukkan dengan terjalinnya komunikasi yang efektif antara aparatur Kesbangpol dengan masyarakat, sehingga pesan pemilu damai sampai ke masyarakat dan terjadi perubahan sikap dan perilaku masyarakat.

Faktor pendukung Kesbangpol dalam Meminimalisir Potensi Konflik pada masa persiapan Pilpres 2019 di wilayah Kabupaten Cianjur adalah SDM, anggaran, SOP dan juknis, dan optimalisasi media sosial. Sementara, faktor penghambat adalah SDM, anggaran, sarana dan prasarana, dan rendahnya budaya literasi di masyarakat.

Adapun rekomendasi sebagai berikut :

1. Bagi Dinas Kesbangpol Kabupaten Cianjur untuk meningkatkan kuantitas aparatur Kesbangpol dengan menambah dan/atau mengoptimalkan personel dari fungsi lainnya. Selain itu, perlu meningkatkan kualitas aparatur kesbangpol melalui pelatihan, khususnya kemampuan komunikasi persuasif.

2. Bagi Dinas Kesbangpol untuk menambah sarana dan prasarana dengan pengajukan tambahan anggaran.

3. Bagi aparatur Kesbangpol untuk memberikan edukasi kepada masyarakat supaya mencari sumber informasi yang benar dan bersikap bijaksana dalam menyikapi suatu berita di media sosial. 
Aparatur Kesbangpol juga ikut memotivasi masyarakat untuk suka membaca sehingga tidak mudah terpengaruh hoax.

\section{DAFTAR PUSTAKA}

Arifin, R. (2020). Crimes and Society, How Do the Law Respond to Disruptive Conditions?. Law Research Review Quarterly, 6(1), i-iv. Retrieved from https://journal.unnes.ac.id/sju/index.php/snh/article/view/37437

Brata, W. P. (2017). Efektivitas Penyuluhan oleh Satuan Binmas dalam Mencegah Tindak Pidana Kekerasan Terhadap Anak di Wilayah Hukum Polres Jepara. Advances in Police Science Research Journal, 1(2), 567-610. Retrieved from http://journal.akpol.ac.id/index.php/apsrj/article/view/29

Pamungkas, A.D., \& Arifin, R. (2019). 'Demokrasi dan Kampanye Hitam dalam Penyelenggaraan Pemilihan Umum di Indonesia (Analisis atas Black Campaign dan Negative Campaign)'. DIKTUM: Jurnal Syariah dan Hukum 17

(1), 16-30. DOI: https://doi.org/10.35905/diktum.v17i1.641

Sugiyono. 2012. Metode Penelitian Kuantitatif, Kualitatif, dan R\&D. Bandung: CV. Alfabeta.

Suparmin. 2014. Pengantar Ekonomi dan Bisnis Bidang Keahlian Bisnis dan Manajemen Untuk SMK/MAK Kelas XI A. Surakarta : CV Mediatama. 